\title{
Clipping date effects on soil water and regrowth in crested wheatgrass
}

\author{
RICHARD F. MILLER, MARSHALL R. HAFERKAMP, AND RAYMOND F. ANGELL
}

\section{Abstract}

Although extensive work has evaluated plant response to season of defoliation, few studies have evaluated the influence of season of defoliation on soil water depletion, amount of regrowth, and total seasonal biomass production. This 5-year study evaluated the effect of clipping date and yearly climatic variation on soil water depletion, amount of regrowth, and total seasonal forage production. Timing of clipping significantly $(P \leq 0.05)$ affected soil water depletion patterns. Clipping at the early vegetative stage had little effect on soil water potential unless soil water potentials were below-0.03 MPa. In mid June soils beneath plants defoliated during the boot stage were consistently wetter than soils beneath undefoliated plants. However, total seasonal soil water depletion was usually similar among treatments by the end of the growing season. Phenology and the amount of standing crop present when defoliation occurred were significantly $(P \leq 0.05, \mathbf{R 2}=0.877)$ correlated with regrowth. Date of defoliation also significantly $(P \leq 0.05)$ affected total production in wet years. Total seasonal forage production on plots clipped during the boot stage was generally lower than on plots clipped during the vegetative or late-flowering stages of development.

Key Words: soil moisture, biomass, regrowth $A$ gropyron desertorum

Considerable research has evaluated the effects of defoliation on carbohydrate levels, shoot production, root growth, and photosynthesis of crested wheatgrass (Agropyron desertorum (Fisch. ex Link) Schult) (Hyder and Sneva 1963, Frischknecht and Harris 1968, Currie and Smith 1970, Sharp 1970, Caldwell et al. 1981, Nowak and Caldwell 1984, Richards 1984, Richards and Caldwell 1985). Few studies, however, have determined the effects of defoliation on soil water content, current year's forage production, and potential regrowth. Gifford and Springer (1980) and Blackburn et al. (1982) indicated that little research has evaluated the effect of grazing on soil water depletion on arid and semiarid rangelands. Recently, Wraith et al. (1987) reported that time of grazing influenced soil water depletion rate during spring. Information on the influence of grazing and annual weather variability on soil water depletion, amount of regrowth and total seasonal forage production should aid in adjusting intensive grazing plans. Defining potential changes in seasonal soil water depletion patterns caused by defoliation may also help predict shifts in plant species composition. Differences in soil water depletion patterns during the growing season may influence growth and competitive interactions of ungrazed plants (Wraith et al. 1987).

The purpose of this 5-year study was to test the hypotheses that: (1) clipping date and yearly climatic variation affect seasonal soil water depletion rates; (2) clipping date and year affect total sea-

Authors are professor of rangeland resources, Eastern Oregon Agricultural Research Center, Oregon State University, Burns 97720; plant physiologist, USDAARS, Ft. Keogh Livestock and Range Research Laboratory, Miles City, Montana 59301; and range scientist, USDA-ARS, Eastern Oregon Agricultural Research Center, Burns 97720.

The Eastern Oregon Agricultural Research Center, including Squaw Butte and Union Stations, is jointly operated by the Oregon Agricultural Experiment Station and USDA Agricultural Research Service.

This article is Technical Paper 8832.

Manuscript accepted $19 \mathrm{July} 1989$. sonal forage production; and (3) soil water content and phenological stage at which clipping occurs affects regrowth potential.

\section{Materials and Methods}

The study was conducted on the Squaw Butte Experimental Range, in southeastern Oregon, $67 \mathrm{~km}$ west of Burns $\left(119^{\circ} 43^{\prime} \mathrm{W}\right.$ latitude, $43^{\circ} 29^{\prime} \mathrm{N}$ longitude, $1,360 \mathrm{~m}$ elevation). This site is located within the Great Basin and is representative of the sagebrushsteppe ecosystem. The 37-year mean annual precipitation for this area is $284 \mathrm{~mm}$ (Table 1), with the majority of moisture received between October and June, mostly as snow. During the study period, crop-year precipitation (September through August) ranged from 68 to $142 \%$ of the 37 -year mean. The mean temperature in winter is $-0.6^{\circ} \mathrm{C}$ with the daily minimum temperature averaging $-4.8^{\circ} \mathrm{C}$, and the mean summer temperature is $17.6^{\circ} \mathrm{C}$, with a mean daily maximum of $26.8^{\circ} \mathrm{C}$. Soils at the study site are coarse-loamy, mixed, frigid Orthic Durixerols approximately $55 \mathrm{~cm}$ deep (Lentz and Simonson 1986). The site was seeded to crested wheatgrass in the late 1960's. Prior to 1982 the pasture was grazed at moderate levels during various periods of the growing season. In late August of 1982 and 1983 the pasture was grazed during summer dormancy to remove standing dead. From 1984 through 1987 the pasture was mowed instead of grazed during summer dormancy.

The study was arranged in a randomized complete-block design with 10 blocks. Ten $3 \times 3-\mathrm{m}$ plots were located in each block. Within each block, 1 quadrat $(1.2 \times 1.8 \mathrm{~m})$ was clipped in the center of each plot to a 2-cm stubble height during one of the defined phenological stages (Table 2). Harvested material was dried for 24 hours at $60^{\circ} \mathrm{C}$ and weighed to estimate current year's standing crop at the time of clipping. Following each clipping treatment, the remainder of the plot, which served as a buffer surrounding the clipped area, was mowed. All plots were again harvested in the same manner in mid August to determine regrowth. Current year's net production was estimated by adding standing crop present at the first clipping to that obtained in August. During the midAugust clipping, the number of reproductive culms was determined. Treatments were established in a new location of the pasture in each of the 5 years of the study.

Soil water content was determined gravimetrically from soil samples collected at the 2-20 and $20-40 \mathrm{~cm}$ depths on each defoliation date. Soil samples were collected in plots to be clipped and plots clipped previously in 5 of the 10 blocks. Soil water samples from plots which had not yet been clipped served as undefoliated controls. Moisture release curves were developed for each of the 2 soil depths and were used to obtain estimates of soil water potential.

Differences in soil water potential among treatments within sampling dates and years were evaluated using analysis of variance procedures (ANOVA). When the ANOVA showed a significant $F$ value, treatment means were separated using least significant differences (LSD) $(P<0.05)$ (Steel and Torrie 1980). When evaluating the effects of season of use on total seasonal forage production and amount of regrowth, a split-plot design was used with years as main plots and date of clipping as subplots. Regression analyses 
Table 1. Monthly precipitation (mm) for the 5-year study and the 37-year mean for the Squaw Butte Experimental Range.

\begin{tabular}{|c|c|c|c|c|c|c|c|c|c|c|c|c|c|}
\hline Crop year & Sept. & Oct. & Nov. & Dec. & Jan. & Feb. & Mar. & Apr. & May & June & July & Aug. & Total \\
\hline $\begin{array}{l}1982-83 \\
1983-84 \\
1984-85 \\
1985-86 \\
1986-87 \\
37 \text {-year mean }\end{array}$ & $\begin{array}{r}49 \\
15 \\
2 \\
38 \\
41 \\
14\end{array}$ & $\begin{array}{r}20 \\
27 \\
45 \\
12 \\
8 \\
23\end{array}$ & $\begin{array}{l}16 \\
45 \\
35 \\
15 \\
19 \\
31\end{array}$ & $\begin{array}{r}37 \\
86 \\
5 \\
32 \\
8 \\
85\end{array}$ & $\begin{array}{r}12 \\
4 \\
22 \\
26 \\
20 \\
34\end{array}$ & $\begin{array}{l}37 \\
11 \\
12 \\
79 \\
25 \\
23\end{array}$ & $\begin{array}{l}53 \\
66 \\
13 \\
30 \\
25 \\
24\end{array}$ & $\begin{array}{l}19 \\
27 \\
12 \\
10 \\
28 \\
20\end{array}$ & $\begin{array}{l}32 \\
17 \\
27 \\
36 \\
34 \\
31\end{array}$ & $\begin{array}{r}10 \\
37 \\
4 \\
8 \\
28 \\
24\end{array}$ & $\begin{array}{r}19 \\
15 \\
7 \\
3 \\
41 \\
9\end{array}$ & $\begin{array}{r}17 \\
53 \\
8 \\
1 \\
8 \\
16\end{array}$ & $\begin{array}{l}320 \\
404 \\
194 \\
291 \\
286 \\
284\end{array}$ \\
\hline
\end{tabular}

were used to determine the relationship of amount of regrowth to phenology and soil water content.

\section{Results}

\section{Soil Water Potential}

Date of clipping significantly $(P<0.05)$ influenced soil water potential during the growing season at both soil depths (Table 3 ). However, fewer differences in soil water potentials were detected in the $20-40 \mathrm{~cm}$ soil depth. The impact of clipping on soil water depletion in the $2-20 \mathrm{~cm}$ depth occurred earlier in the dry years of 1985 and 1987. Soil water potentials in these dry years were near $-0.2 \mathrm{MPa}$ at the beginning of the growing season compared to soil water potentials near or above $-0.03 \mathrm{MPa}$ in other years (Table 4). In the 2 dry years, soil water potentials differed significantly between clipping treatments in mid May 1985 and late April 1987, compared to early June 1983 and late May 1984 and 1986. Clipping during elevation of the apical meristem in late May, consistently decreased soil water depletion rates compared to controls for the $2-20 \mathrm{~cm}$ depth in all 5 years of the study and for the $20-40 \mathrm{~cm}$ depth in 3 of 5 years. Soil water potentials were generally similar among treatments in the upper $20 \mathrm{~cm}$ depth by mid July and the $20-40 \mathrm{~cm}$ depth by mid June.

\section{Regrowth}

A significant clipping stage by year interaction $(P<0.05)$ for regrowth indicated that treatment rankings varied among years (Table 4). Regrowth ranged from 235 to $1,540 \mathrm{~kg} \mathrm{ha}^{-1}$ for plots clipped during the late vegetative stage in mid May and 85 to $568 \mathrm{~kg}$ $\mathrm{ha}^{-1}$ for plots defoliated during elevation of the apical meristem in late May. Regrowth represented 34\% or more of the year's peak standing crop when plants were clipped during the vegetative stage compared to about $21 \%$ for plants clipped during elevation of the apical meristem (early boot). (Fig. 1). During the 5 growing seasons, the amount of regrowth produced by mid August was $64 \%$ less for plants clipped during apical meristem elevation compared to plants clipped 2 weeks earlier during the vegetative stage.

The correlation between amount of regrowth and soil water potential at the time of clipping in the upper $20 \mathrm{~cm}$ was significant $\left(P<.05, \mathrm{R}^{2}=0.71\right)$ (Fig. 2). However, the amount of regrowth

Table 2. Phenological stage and approximate clipping date used for the 5 -years of study.

\begin{tabular}{ll}
\hline \hline Phenological stage & Approximate clipping date \\
\hline 1. early vegetative & mid April \\
2. mid vegetative & late April \\
3. late vegetative & mid May \\
4. early boot (apical meristem & late May \\
elevated) & \\
5. late boot & early June \\
6. early flowering (fully emerged) & mid June \\
7. mid flowering (antehsis) & early July \\
8. late flowering (seed formation) & mid July \\
9. seed set \& senescence & early August \\
10. summer dormancy & mid August \\
\hline
\end{tabular}

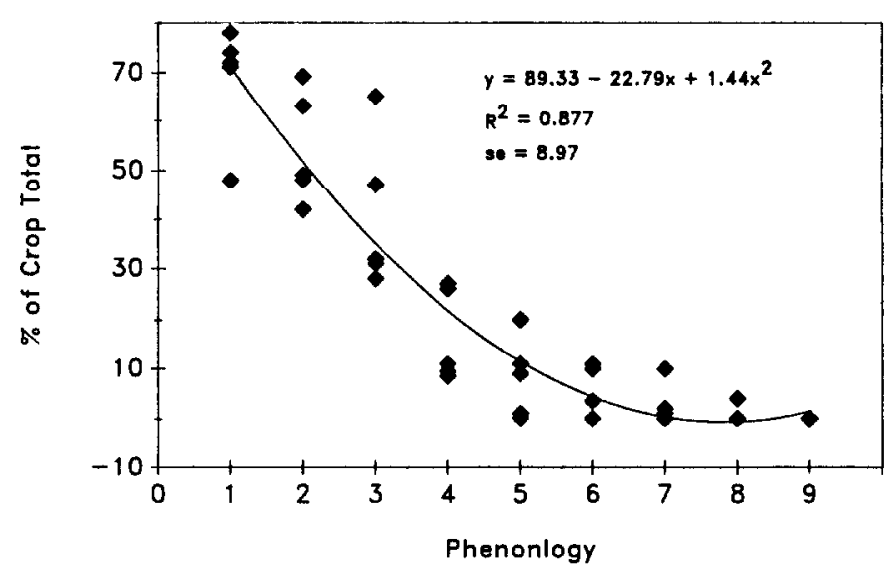

Fig. 1. Regression analysis of the relationship between phenological stage at time of clipping and percent of the year's total forage production contributed by growth following clipping. Data represent 9 stages of phenology and 5 growing seasons (1983 to 1987). Phenology is on a scale from 1 to 9 , as per Table 2.

predicted for plants clipped in the early and late boot stages was usually overestimated. This was especially true for 1984 , which received $142 \%$ of normal precipitation. Soil water content below 20 $\mathrm{cm}$ was also significantly correlated with regrowth $\left(P<0.05, R^{2}=\right.$ 0.64). The best predictor of potential forage growth following clipping, however, was phenological stage coupled with standing crop at the time of clipping. For example, in $1986,714 \mathrm{~kg} \mathrm{ha}^{-1}$ of standing crop was present during the late vegetative (stage 3 ); this would represent $66 \%$ of the total yield (Fig. 1). Consequently, estimated total season forage production would be $1,082 \mathrm{~kg} \mathrm{ha}^{-1}$. In the wet years, 1983 and 1984, regrowth was underestimated during the mid to late vegetative stages.

\section{Annual Yield}

Aboveground production also exhibited a significant clipping

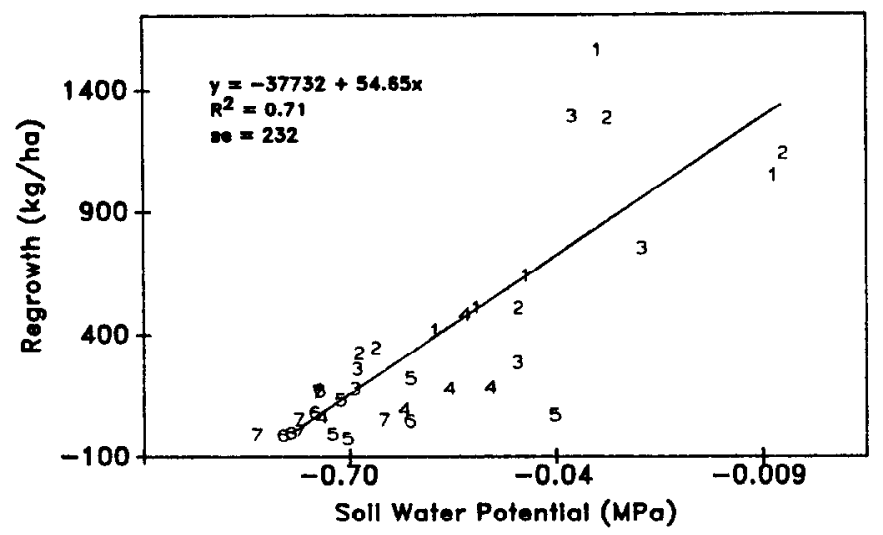

Fig. 2. Regression analysis between soil water potential (log10 scale) and regrowth production for the 9 clipping dates for 1983 through 1987. 
Table 3. Soil water potential (MPa) for sampling dates in which significant differences $(P<0.05)$ occurred between clipping treatments. Last value in each row is the control (unclipped) treatment.

\begin{tabular}{|c|c|c|c|c|c|c|c|c|c|c|c|}
\hline \multirow[b]{3}{*}{ Year } & \multirow{3}{*}{$\begin{array}{l}\text { Soil Water } \\
\text { Sampling } \\
\text { Date }\end{array}$} & \multicolumn{10}{|c|}{ Phenological stage of clipping } \\
\hline & & \multicolumn{2}{|c|}{ April } & \multicolumn{2}{|c|}{ May } & \multicolumn{2}{|c|}{ June } & \multicolumn{2}{|c|}{ July } & \multicolumn{2}{|c|}{ August } \\
\hline & & $\begin{array}{l}\text { Early } \\
\text { Veg }\end{array}$ & $\begin{array}{l}\text { Mid } \\
\text { Veg }\end{array}$ & $\begin{array}{l}\text { Late } \\
\text { Veg }\end{array}$ & $\begin{array}{l}\text { Early } \\
\text { Boot }\end{array}$ & $\begin{array}{l}\text { Late } \\
\text { Boot }\end{array}$ & $\begin{array}{l}\text { Early } \\
\text { Flower }\end{array}$ & $\begin{array}{l}\text { Mid } \\
\text { Flower }\end{array}$ & $\begin{array}{l}\text { Late } \\
\text { Flower }\end{array}$ & $\begin{array}{l}\text { Seed } \\
\text { Set }\end{array}$ & Dormant \\
\hline \multicolumn{12}{|c|}{ MPA } \\
\hline \multicolumn{12}{|c|}{ Soil Depth 2-20 cm } \\
\hline 1983 & $\begin{array}{l}\text { Early June' } \\
\text { Mid June } \\
\text { Early July }\end{array}$ & $\begin{array}{l}-0.40^{\mathrm{a} 2} \\
-1.55^{\mathrm{a}} \\
-0.56^{\mathrm{abc}}\end{array}$ & $\begin{array}{l}-0.44^{a} \\
-1.84^{a} \\
-0.61^{a b}\end{array}$ & $\begin{array}{l}-0.28^{b} \\
-1.07^{b} \\
-0.44^{c d}\end{array}$ & $\begin{array}{l}-0.25^{b} \\
-0.60^{c} \\
-0.49^{b c d}\end{array}$ & $\begin{array}{l}-0.43^{\mathrm{a}} \\
-0.93^{\mathrm{b}} \\
-0.38^{\mathrm{d}}\end{array}$ & $\begin{array}{l}-1.66^{\mathrm{a}} \\
-0.57^{\mathrm{abc}}\end{array}$ & $-0.69^{a}$ & & & \\
\hline 1984 & $\begin{array}{l}\text { Late May } \\
\text { Mid June } \\
\text { Early July } \\
\text { Mid August }\end{array}$ & $\begin{array}{c}-0.16^{\mathrm{ab}} \\
-0.83^{\mathrm{a}} \\
-6.80^{\mathrm{a}}\end{array}$ & $\begin{array}{c}-0.12^{\mathrm{b}} \\
-0.77^{\mathrm{a}} \\
-\overline{1} \\
-7.19^{\mathrm{a}}\end{array}$ & $\begin{array}{l}-0.17^{a b} \\
-0.79^{a} \\
-7.19^{a}\end{array}$ & $\begin{array}{l}-0.23^{\mathrm{a}} \\
-0.37^{\mathrm{c}} \\
-1.41^{\mathrm{b}} \\
-6.44^{\mathrm{a}}\end{array}$ & $\frac{-0.50^{d}}{-4.51^{\mathrm{ab}}}$ & $\begin{array}{l}-0.53^{b} \\
-3.15^{b}\end{array}$ & $\begin{array}{l}-2.57^{a} \\
-4.97^{\mathrm{ab}}\end{array}$ & $-4.30^{a b}$ & $-6.10^{a}$ & $-8.06^{n}$ \\
\hline 1985 & $\begin{array}{l}\text { Mid May } \\
\text { Late May } \\
\text { Early June } \\
\text { Mid June } \\
\text { Early July }\end{array}$ & $\begin{array}{l}-0.53^{\mathrm{b}} \\
-0.75^{\mathrm{b}} \\
-1.01^{\mathrm{ab}} \\
-1.78^{\mathrm{b}} \\
-6.44^{\mathrm{ab}}\end{array}$ & $\begin{array}{l}-0.69^{\mathrm{ab}} \\
-0.98^{\mathrm{b}} \\
-1.04^{\mathrm{ab}} \\
-2.90^{\mathrm{a}} \\
-7.61^{\mathrm{a}}\end{array}$ & $\begin{array}{l}-0.95 \mathrm{a}^{\mathrm{a}} \\
-0.90^{\mathrm{b}} \\
-0.75^{\mathrm{b}} \\
-2.20^{\mathrm{ab}} \\
-6.10^{\mathrm{ab}}\end{array}$ & $\begin{array}{l}-1.55^{\mathrm{a}} \\
-0.71^{\mathrm{b}} \\
-1.84^{\mathrm{b}} \\
-3.29^{\mathrm{c}}\end{array}$ & $\begin{array}{l}-1.41^{\mathrm{a}} \\
-1.66^{\mathrm{b}} \\
-4.30^{\mathrm{bc}}\end{array}$ & $\begin{array}{l}-3.02^{a} \\
-6.44^{a}\end{array}$ & $-7.61^{a}$ & & & \\
\hline 1986 & $\begin{array}{l}\text { Late May } \\
\text { Early June } \\
\text { Mid June }\end{array}$ & $\begin{array}{l}-0.49^{\mathrm{ab}} \\
-1.04^{\mathrm{a}} \\
-3.15^{\mathrm{a}}\end{array}$ & $\begin{array}{l}-0.35^{\mathrm{b}} \\
-0.83^{\mathrm{ab}} \\
-2.78^{\mathrm{a}}\end{array}$ & $\begin{array}{l}-0.30^{\mathrm{b}} \\
-0.71^{\mathrm{ab}} \\
-2.57^{\mathrm{a}}\end{array}$ & $\begin{array}{l}-0.53^{a} \\
-0.60^{b} \\
-1.78^{b}\end{array}$ & $\begin{array}{l}-1.10^{\mathrm{a}} \\
-2.90^{\mathrm{a}}\end{array}$ & $-3.43^{a}$ & & & & \\
\hline 1987 & $\begin{array}{l}\text { Late April } \\
\text { Mid May } \\
\text { Mid June }\end{array}$ & $\begin{array}{l}-0.51^{b} \\
-0.64^{b} \\
-1.07^{b c}\end{array}$ & $\begin{array}{l}-0.93^{a} \\
-0.50^{b} \\
-1.01^{b c}\end{array}$ & $\begin{array}{l}-1.04^{\mathrm{a}} \\
-1.35^{\mathrm{ab}}\end{array}$ & $-0.90^{c}$ & $-0.95^{b c}$ & $-1.78^{\mathrm{a}}$ & & & & \\
\hline \multicolumn{12}{|c|}{ Soil Depth $20-40 \mathrm{~cm}$} \\
\hline 1983 & $\begin{array}{l}\text { Early June } \\
\text { Mid June }\end{array}$ & $\begin{array}{l}-0.33^{a b c} \\
-0.65^{a b}\end{array}$ & $\begin{array}{l}-0.35^{\mathrm{ab}} \\
-0.95^{\mathrm{a}}\end{array}$ & $\begin{array}{l}-0.29^{\mathrm{bc}} \\
-0.43^{\mathrm{bc}}\end{array}$ & $\begin{array}{l}-0.26^{\mathrm{c}} \\
-0.31^{\mathrm{c}}\end{array}$ & $\begin{array}{l}-0.39^{\mathrm{a}} \\
-0.90^{\mathrm{a}}\end{array}$ & $-0.88^{\mathrm{a}}$ & & & & \\
\hline 1985 & Late May & $-0.39^{c}$ & $-0.54^{b c}$ & $-0.62^{\mathrm{ab}}$ & $-0.82^{\mathrm{a}}$ & & & & & & \\
\hline 1986 & $\begin{array}{l}\text { Late May } \\
\text { Early June } \\
\text { Mid June } \\
\text { Mid July }\end{array}$ & $\begin{array}{l}-0.33^{\mathrm{a}} \\
-0.65^{\mathrm{a}} \\
-4.23^{\mathrm{a}} \\
-7.73^{\mathrm{ab}}\end{array}$ & $\begin{array}{l}-0.31^{\mathrm{ab}} \\
-0.44^{\mathrm{ab}} \\
-3.32^{\mathrm{ab}} \\
-7.94^{\mathrm{a}}\end{array}$ & $\begin{array}{l}-0.25^{\mathrm{b}} \\
-0.36^{\mathrm{b}} \\
-2.56^{\mathrm{b}} \\
-7.82^{\mathrm{a}}\end{array}$ & $\begin{array}{l}-0.34^{\mathrm{a}} \\
-0.35^{\mathrm{b}} \\
-0.93^{\mathrm{c}} \\
-5.26^{\mathrm{b}}\end{array}$ & $\begin{array}{l}-0.62^{\mathrm{a}} \\
-2.56^{\mathrm{b}} \\
-7.00^{\mathrm{ab}}\end{array}$ & $\begin{array}{l}-5.51^{\mathrm{a}} \\
-7.85^{\mathrm{a}}\end{array}$ & $-7.94^{\mathrm{a}}$ & & & \\
\hline 1987 & $\begin{array}{l}\text { Mid May } \\
\text { Mid June }\end{array}$ & $\begin{array}{l}-0.93^{b} \\
-1.57^{b c}\end{array}$ & $\begin{array}{l}-0.71^{b} \\
-1.48^{b c}\end{array}$ & $\begin{array}{l}-1.52^{\mathrm{a}} \\
-2.02^{\mathrm{ab}}\end{array}$ & $-1.32^{c}$ & $-1.39^{b c}$ & $-2.66^{\mathrm{a}}$ & & & & \\
\hline
\end{tabular}

IOnly soil water sampling dates that exhibited significant differences $(P<0.05)$ between treatments are shown.

'Soil water potentials with the same lower case letter are not significantly different $(P>0.05)$ between clipping dates within each soil water sampling date.

stage by year interaction (Table 5). For the wet years of 1983 and 1984 , clipping reduced total forage production most during rapid growth in the late vegetative through late boot stages, mid May through early June. Total seasonal forage production in these 2 years was reduced 50 to $55 \%$ of the peak standing crop occurring in the mid to late flowering stages. These differences were not apparent for the relatively drier years of 1985, 1986, and 1987.

\section{Discussion}

Despite the yearly variation in growing conditions, apical meristems of crested wheatgrass plants remained below $1 \mathrm{~cm}$ through mid May and were elevated above $1 \mathrm{~cm}$ by late May for all 5 years of our study. Apical meristems were elevated following leaf removal on tillers clipped prior to late May, resulting in elongated internodes and the production of inflorescences. Growth following clipping in late May, however, was primarily attributed to secon-

Table 4. Soil water potential (MPa) at the beginning of the growing season (mid-April) for the 5 growing seasons.

\begin{tabular}{lccccc}
\hline & 1983 & 1984 & 1985 & 1986 & 1987 \\
\hline Soil water potential & $-0.03 \mathrm{a}^{\prime}$ & $-0.10 \mathrm{~b}$ & $-0.20 \mathrm{c}$ & $-0.03 \mathrm{a}$ & $-0.20 \mathrm{c}$ \\
\hline
\end{tabular}

Table 5. Regrowth ( $\mathrm{kg} / \mathrm{ha}$ ) occurring after clipping at 10 phenological stages for 5 growing seasons. Although there was a significant interaction between clipping stage $X$ year, clipping stage differences and year differences are highly significant (Petersen 1985).

\begin{tabular}{lrrrrr}
\hline \hline Clipping stage & 1983 & 1984 & 1985 & 1986 & 1987 \\
\hline Early vegetation & 1839 & 1239 & 496 & 765 & 607 \\
Mid vegetation & 1524 & 1365 & 430 & 616 & 402 \\
Late vegetation & 1540 & 916 & 319 & 376 & 235 \\
Apical M. & 568 & 230 & 85 & 125 & 216 \\
Late boot & 269 & 118 & 6 & 5 & 164 \\
Flowering & 217 & 74 & 0 & 0 & 102 \\
Anthesis & 72 & 43 & 0 & 0 & 75 \\
Seed formation & 0 & 0 & 0 & 0 & 44 \\
Seed set senescence & 0 & 0 & 0 & 0 & 0 \\
Dormancy & 0 & 0 & 0 & 0 & 0 \\
\hline
\end{tabular}

LSD (treatment, 0.05 ) $=434$

$\operatorname{LSD}($ year, 0.05$)=506$ 
Table 6. Years total forage production ( $\mathrm{kg} / \mathrm{ha}$ ) (first clipping + mid August clipping) for each treatment (phenological stage of initial clipping) over the 5 years. Although there was a significant interaction between clipping stage $X$ year, clipping stage differences and year differences are highly significant (Petersen 1985).

\begin{tabular}{lrrrrr}
\hline \hline & \multicolumn{5}{c}{ Year } \\
\cline { 2 - 6 } Clipping stage & 1983 & 1984 & 1985 & 1986 & 1987 \\
\hline Early vegetative & 2112 & 1326 & 723 & 1188 & 981 \\
Mid vegetative & 1800 & 1655 & 812 & 1114 & 858 \\
Late vegetative & 1928 & 1291 & 874 & 1053 & 815 \\
Early boot & 1323 & 876 & 806 & 944 & 1030 \\
Late boot & 1488 & 1208 & 998 & 1107 & 855 \\
Early flowering & 1926 & 1082 & 1008 & 1227 & 920 \\
Mid flowering & 2410 & 1548 & 972 & 1177 & 850 \\
Late flowering & 2240 & 1755 & 972 & 1150 & 831 \\
Senescence & 2133 & 1889 & 885 & 1204 & 730 \\
Dormancy & 1966 & 1704 & 725 & 1130 & 731 \\
\hline
\end{tabular}

LSD (Treatment, 0.05$)=86.2$

$\operatorname{LSD}($ Year, 0.05$)=76.0$

dary tillering, stimulated by removal of the apical meristem. These findings agree with those of Sharp (1970), who reported that apical meristems of crested wheatgrass were removed by grazing about 20 May.

Total seasonal forage production was reduced most markedly by clipping in the wet years, resulting from removal of the apical meristem and subsequent reduction of reproductive stem development and delayed growth. In the wet years a larger proportion of tillers were differentiated into reproductive shoots as compared to the 3 drier years. Hyder and Sneva (1963) reported that favorable growth conditions resulted in a higher proportion of apical meristems being differentiated to reproductive status than less favorable growth conditions, and that removal of the apical meristem resulted in $90 \%$ of the second crop tillers being vegetative. Others also reported delayed growth when apical meristems were removed (Cook and Stoddart 1953, Richard and Caldwell 1985, Olson and Richards 1988). Olson and Richards (1988) noted that shoot production from axillary buds reached a maximum 2 to 3 weeks following defoliation of crested wheatgrass.

The amount of regrowth after clipping at a defined phenological stage exhibited considerable yearly variability. The amount of standing crop present at a specific phenological stage was a better indicator of potential regrowth than current soil water status. Peak standing crop in 1984 was $22 \%$ less than 1983 even though total precipitation was $26 \%$ greater and soil water potential higher throughout the 1984 growing season. A direct relationship between plant production and total precipitation does not always exist (Charley 1972, Ludwig and Flavill 1979, Sneva and Britton 1983). Factors such as wind, humidity, temperature fluxes, distribution of precipitation and available soil nitrogen may also affect plant growth. These factors may influence the amount of water allocated between transpiration and evaporation. Available soil nitrogen may have been more limiting in 1984 due to the preceding wetter than normal years of 1982 and 1983 . Others have reported reduced productivity in semiarid communities in the second of 2 (Charley 1972) and the third of 3 consecutive wet years (Sneva and Britton 1983). These authors attributed reduced productivity to the amount of available nitrogen. Prolonged growth, following removal of apical meristems in 1987 (Table 5), may have been stimulated by above normal precipitation in May, June, and July (Table 1). In addition, prolonged regrowth may have been influenced by increased nitrogen availability due to frequent wetting events (Fisher et al. 1988) in the later part of the growing season and the 2 previous years of average and below-average precipitation.

The reduction in soil water depletion resulting from clipping was probably attributable to both leaf area removal and reduced root growth (Caldwell et al. 1981, Richards 1984). Defoliation in the early vegetative stage generally had little effect on soil water content unless soil water potentials were more negative than -0.03 $\mathrm{MPa}$. Reduced soil water depletion after defoliation during early stages of apical meristem elevation was probably caused by reduced leaf area and the subsequent delay in leaf initiation from axillary buds. Effects of defoliation on soil water depletion and the similarity of soil water contents between grazing treatments at the end of the growing season were also noted by Wraith et al. (1987). Delayed soil moisture depletion may increase the period of availability of active plant growth for grazing. This was most evident during the 2 wet years when regrowth occurred from axillary tillers and senescence was delayed. However, the delay would result in shifting growth to periods with greater water demands and subsequent lowered water use efficiency. This delay may also increase water availability for ungrazed competing plants in the pasture such as sagebrush (Artemisia tridentata).

The yearly variability in total seasonal forage production and amount of regrowth available for late summer or fall use makes planning intensive grazing difficult. If standing crop in a crested wheatgrass pasture declines below $134 \mathrm{~kg} \mathrm{dry}_{\text {matter }} \mathrm{ha}^{-1}$ intake by cattle will be limited (Handl and Rittenhouse 1972). In our study, even in a dry year receiving only $68 \%$ of normal precipitation, regrowth by mid August was adequate for cattle if defoliation preceded elevation of the apical meristem. Sneva (1973) reported that $52 \%$ of the total yield of crested wheatgrass was generally present by 15 May in a 13-year study period. If the management objective, however, is to produce a second crop of higher quality forage by removing the apical meristem in late May (Hyder and Sneva 1963), attaining adequate regrowth for a second crop is not always reliable. During the growing seasons of 1983 through 1987 , regrowth would have been adequate in 3 of 5 years. Similarly, Hedrick et al. (1969) reported that regrowth following removal of the apical meristem was adequate in only 2 of 5 years.

Further work is needed to determine the impact of altering soil water depletion patterns on plant community composition. Research needs to address the extent that delaying soil water depletion may increase the growth, reproductive effect, and seedling establishment of undesirable plants.

\section{Literature Cited}

Blackburn, W.H., R.W. Knight, and M.K. Wood. 1982. Impact of grazing on watersheds: a state of knowledge. Texas Agr. Exp. Sta. Misc. Pub. 1496.

Caldwell, M.M., J.H. Richards, D.A. Johnson, R.S. Nowak, and R.S. Dzurec. 1981. Coping with herbivory: photosynthetic capacity and resource allocation in two semiarid Agropyron bunchgrasses. Oecologia 50:14-24.

Charley, J.L. 1972. The role of shrubs in nutrient cycling, p. 182-203. In: C.M. McKell, J.P. Blaisdell, and J.R. Goodwin (eds), Wildland shrubstheir biology and utilization. USDA Forest Serv. Gen. Tech. Rep. INT1, Washington, D.C.

Cook, C.W., and L.A. Stoddart. 1953. Some growth responses of crested wheatgrass following herbage removal. J. Range Manage. 6:267-270.

Currie, P.O., and D.W.Smith. 1970. Response of seeded ranges to different grazing intensities. Prod. Res. Rep. 112, USDA Forest Serv. U.S. Govern. Printing Off., Washington, D.C.

Fisher, F.M., J.C. Zak, G.L. Cunningham, and W.G. Whitford. 1988. Water and nitrogen effects on growth and allocation patterns of creosotebush in the northern Chihuahuan Desert. J. Range Manage. 41:387-391.

Frischknecht, N.C., and L.E. Harris. 1968. Grazing intensities and systems on crested wheatgrass in central Utah: Response of vegetation and cattle. Tech. Bull 1388. USDA Forest Serv. U.S. Govern. Printing Off. Washington, D.C.

Gifford, G.F., and E.P. Springer. 1980. A selected annotated bibliography on grazing hydrology. Utah Agr. Exp. Sta. Res. Rep. 50. 
Handl, W.P., and L.R. Rittenhouse. 1972. Herbage yield and intake of grazing steers. Proc. West. Sec. Amer. Soc. Animal Sci. 23:197-200.

Hedrick, D.W., W.M. Moser, A.L. Steinger, and R.A. Long. 1969. Animal performance on crested wheatgrass pastures during May and June, Fort Rock, Oregon. J. Range Manage. 22:277-280.

Hyder, D.N., and F.A. Sneva. 1963. Morphological and physiological factors affecting the grazing management of crested wheatgrass. Crop Sci. 3:267-271.

Lentz, R.D., and G.H. Simonson. 1986. A detailed soils inventory and associated vegetation of Squaw Butte Range Experiment Station. Oregon State Univ. Agr. Exp. Sta. Spec. Rep. 760.

Ludwig, J.A., and P. Flavill. 1979. Productivity patterns of Larrea in the northern Chihuahuan Desert, p. 139-150. In: E.C. Lopez, T.J. Mabry, and S.F. Tavison (eds), Larrea. Serie el Desierto, Vol. 2 Centro de Investigacion en Quimica Aplicada, Saltillo, Coahuila, Mexico.

Nowak, R.S., and M.M. Caldwell. 1984. A test of compensatory photosynthesis in the field: Implications for herbivory tolerance. Oecologia 61:311-318.

Olson, B.E., and J.H. Richards. 1988. Tussock regrowth after grazing: Intercalary meristem and axillary bud activity of tillers of Agropyron desertorum. Oikos 51:374-382.
Petersen, R.G. 1985. Design and analysis of experiments. Marcel Dekker, Inc. N.Y.

Richards, J.H. 1984. Root growth response to defoliation in two Agropyron bunchgrasses: field observations with an improved root periscope. Oecologia 64:21-25.

Richards, J.H., and M.M. Caldwell. 1985. Soluble carbohydrates, concurrent photosynthesis and efficiency in regrowth following defoliation: a field study with Agropyron species. J. Appl. Ecol. 22:907-920.

Sharp, L.A. 1970. Suggested management programs for grazing crested wheatgrass. Univ. Idaho, Forest, Wildlife, and Range Exp. Sta. Bull. 4.

Sneva, F.A. 1973. Crested wheatgrass response to nitrogen and clipping. J. Range Manage. 26:47-50.

Sneva, F.A., and C.M. Britton. 1983. Adjusting and forecasting herbage yields in the intermountain big sagebrush region of the steppe province. Oregon Agr. Exp. Sta. Oregon State Univ. Sta. Bull. 659.

Steel, R.G.D., and J.H. Torrie. 1980. Principles and procedures of statistics. A biometric approach. 2nd ed. Mcgraw-Hill, Inc, Highstown, N.J.

Wraith, J.M., D.A. Johnson, R.J. Hanks, and D.V. Sisson. 1987. Soil and plant water relations in a crested wheatgrass pasture: response to spring grazing by cattle. Oecologia 73:573-578. 